\title{
Narrating Islamism in Indonesia: State, Agency, and Social Resilience
}

\author{
MAUFUR \\ Institute Agama Islam Negeri - Kediri \\ maufur_nd@yahoo.com
}

\begin{abstract}
Islamism or the so-called political Islam is conceptualized as a socio-political rather than a solely religious phenomenon. Inherently characterized by a singularly defined religious concept of purity and a clear-cut distinction between "we" and "them", it manifests into a various form of activities where "terrorism" is the most violent one. Following a series of terrorist attacks in the country, the Indonesian government through The National Counter-Terrorism Agency (BNPT) launched a de-radicalization program that aims to restrain and combat religious radicalism and "terrorism", particularly through its "stick and carrot" approach. Despite its success story in pacifying some terrorist activities in the country, the program is severely criticized for not dealing with the root causes of terrorism. It is also considered counter-productive as it creates resistance and hatred toward the state for specifically targeting Islam and, therefore, it provides incentives for religious radicalism and terrorism. The research conducted in Yogyakarta Province found that Islamism spreads and gains acceptance in certain sections in public through certain social channels and agencies. However, this paper argues that the existing cultural virtues and local wisdom could create social resilience against such radicalization process.

[Islamisme atau yang biasa disebut dengan Islam politik dikonseptualisasikan sebagai fenomena sosial-politik dan bukan semata-mata agama. Secara inheren dicirikan oleh konsep religius yang murni tentang kemurnian dan perbedaan yang jelas antara "kita" dan "mereka", itu termanifestasi ke dalam berbagai bentuk kegiatan, di mana "terorisme" adalah yang paling kejam. Menyusul serangkaian serangan teroris di negara itu, pemerintah Indonesia melalui Badan Nasional Penanggulangan Terorisme (BNPT) meluncurkan program deradikalisasi yang bertujuan
\end{abstract}


untuk menahan dan memerangi radikalisme agama dan "terorisme", terutama melalui "tongkat dan wortel" pendekatan. Terlepas dari kisah suksesnya dalam menenangkan beberapa kegiatan teroris di negara ini, program ini sangat dikritik karena tidak berurusan dengan akar penyebab terorisme. Ia juga dianggap kontraproduktif karena menciptakan perlawanan dan kebencian terhadap negara karena secara khusus menargetkan Islam dan karenanya, memberikan insentif bagi radikalisme agama dan terorisme. Penelitian yang dilakukan di Provinsi Yogyakarta menemukan bahwa Islamisme menyebar dan memperoleh penerimaan di bagian-bagian tertentu di depan umum melalui saluran dan lembaga sosial tertentu. Namun, artikel ini berpendapat bahwa keutamaan budaya yang ada dan kearifan lokal dapat menciptakan ketahanan sosial terhadap proses radikalisasi tersebut.]

Keywords: Islamism, radicalism, terrorism, local wisdom.

\section{Introduction}

The series of current religiously motivated terrorist attacks remind the world of the two-sided coin of religion: peaceful and violent element. Following the 9/11 attacks, the world came into a common word of "war against terror" in which religious radicalism, mostly "Islamist terrorists", becomes a main target. Indonesia, as the world's Muslim largest country, is also positioned at the frontline of this war. It is not only because a number of terrorist attacks targeted the country but also because Indonesia is a "fertile ground" for terrorist networks to grow and evolve.

Being fully aware of that, the Indonesian government took significant efforts to deal with terrorism. After long studies and assessments, in 2010 the government officially launched a non-ministerial department called The National Counter Terrorism Agency (later written as BNPT in this paper) whose first mandate is to cope with terrorism. Since the beginning of its establishment, the agency showed the public its success story of uncovering terrorist networks as well as seizing their actors in Indonesia. Through its special force called Densus 88 (the special task force 88), BNPT successfully convinced the public on its efficient "stick and carrot" 
approach in dealing with terrorism. In some cases, the actual siege and military attacks by Densus 88 toward those suspected terrorists, most of which ended up with the deadly shots of them, were broadcasted live on TVs or widely covered by national newspapers.

Despite its success story, BNPT is, nevertheless, criticized for not properly tackling the roots of terrorism. It is mainly based on the fact that the agency failed to cut off the terrorist networks in Indonesia which continued to develop and mutate its radical ideology into new cells and various agencies. In addition, Indonesia is still considered one among countries that are vulnerable to religious radicalism and terrorism. A survey conducted by Lazurdi Birru (2010) showed that Indonesia's vulnerability to radicalism and terrorism is $43,6 \%$, which is still relatively high. The survey was conducted in 33 provinces using indicators such as radical acts and attitudes, jihadism, Islamist agenda, supports toward radical organizations. The survey by PPIM UIN Jakarta (2015) also found out that religious radicalism in Indonesia have reached out larger segments of societies leading, therefore, to a more religiously conservative landscape or what the so-called a 'conservative turn'. Therefore, rather than a "stick and carrot" approach which provides only an ad hoc answer, "war against terror" in Indonesia requires a holistic and comprehensive strategy for which Islamism as a concept could be best used for tools of analysis.

Islamism or the so-called political Islam is conceptualized as a sociopolitical, rather than a solely religious phenomenon (Mozaffari, 2007). Inherently characterized by a singularly defined religious concept of purity and a clear-cut distinction between "we" and "them", it manifests into a various form of activities where "terrorism" is the most violent one. In Indonesia, economic and political instability, globalization and Western policies toward Muslim countries contributed to the growth of Islamism, in addition to other factors at psychological and individual levels, which emerges as an alternative solution for its supporters. Using Islamism as an umbrella term, this paper attempts to provide an analysis of Islamic radicalism and terrorism by focusing on its narratives which gains its resonance among various agencies. Halverson (2011) defines a narrative 
as "coherent system of interrelated and sequentially organized stories that share a common rhetorical desire to resolve a conflict by establishing audience expectations according to the known trajectories of its literary and rhetorical form." Accordingly, the narrative approach is used in this article in order to figure out how Islamism spreads among the agencies and, therefore, their vulnerability to religious radicalism and terrorism as well.

Yogyakarta was chosen as the locus of this research for several reasons: Yogyakarta is the heart of Javanese culture which is well known for its permissiveness toward foreign elements. It has a long history with Islamic radical groups who are in contestation with syncretic Islam. Majelis Mujabidin Indonesia (MMI), for example, was declared in Yogyakarta on August 7, 2000, during the $51^{\text {st }}$ celebration of Islamic State of Indonesia (NII) (Turmudi \& Sihbudi, 2005). Its strategic position as a destination of urbanization strengthens the city's multi-ethnic and religious diversity of the people who become more polarized. Being declared as a city of education, thousands of youth coming from different regions in Indonesia are studying in different universities in the city. As the Sultan of Yogyakarta himself admitted (Shidqi, 2008), the socio-religious landscape of Yogyakarta is currently undergoing changes that endanger its "city of tolerance" identity due to several religiously nuanced intolerance and terrors by some religious groups.

Therefore, it is interesting to examine how the state deals with the spectrum of Islamism in Yogyakarta. As this paper will point out later, "De-radicalization Program" nationally launched by BNPT to some extent creates resistance and hatred toward the state for specifically targeting Islam and, therefore, it provides incentives for religious radicalism and terrorism. However, the existing cultural virtues and local wisdom in Yogyakarta can create social resilience through which the de-radicalization program may be best channeled. 


\section{Mapping Islamism in Yogyakarta: A Narrative Approach}

This section attempts to map the narratives of Islamism which spread and receive social acceptance in Yogyakarta. The informants were selected from different backgrounds which represent various segments of societies in Yogyakarta. By using the matrix of Islamism, i.e. militancy, radicalism, extremism, and terrorism this section examines how Islamism is reflected into narratives among the informants. However, it is important to note here that these categories are not closed ones, rather overlapped to each other. Militancy refers to intolerance and commitments to take a distance from others who are considered unbelievers or deviants. Radicalism assumes desires and aspirations toward the radical change of political or social systems through the establishment of an Islamic political order. While these two categories do not necessitate violence for the aspired changes, extremism transforms into violent acts because of impatience for changes. Terrorism is the peak of Islamism where it involves systematized tactics or strategies to impose immediate changes by uses of violence and terrors (Noorhaidi et. al., 2013).

Yogyakarta is a multi-ethnic society where Islamism is in day-to-day contestation with different ideologies. Even though Yogyakarta is wellknown as a city of tolerance, it nevertheless shows intolerance or at least passive tolerance toward the others. Intolerance, defined as unwillingness or incapability to accept others' different faiths, is reflected on theology as an identity marker when getting along with non-Muslims. Meaning to say, tolerance toward others is encouraged as long as it does not touch theological aspects. The Quranic verse (109: 6) ${ }^{1}$ constitutes the basis of tolerant attitudes toward others. In the informants' words, "we are fine getting along and cooperating with non-Muslims as long as it is only at social and not theological levels."

However, this lazy tolerance does not distinguish clearly the boundaries between what is theological and social. In many cases, the two are confused and overlapped to each other. Consequently, the seemingly

${ }^{1}$ QS. al-Kafirun [109]: 6. 
tolerant attitudes transform into intolerance at a practical level. Asked about the establishment of churches, for example, most informants said that churches should not be established in places where the majority is Muslims. The same attitudes found its fuel as Islamization in Yogyakarta is getting stronger. "Hanya Menerima Kost Muslim (Rent for Muslims Only)" or "Hanya Menerima Kost untuk. Muslim Berjilbab (Rent for Muslim Women with Hijabs Only)," are easily found in front of rent houses in Yogyakarta.

This lazy tolerance explains also why narratives of antiChristianization are not as strong as those toward allegedly deviant Islamic sects such as Ahmadiyah and Shi'ah or even liberal Muslim group such as JIL. "Ahmadiyah Sesat (Ahmadiyah is Deviant)" or "Shiah itu Sesat (Shi'ah is Deviant)" are freely distributed or displayed in forms of posters or pamphlets. Unlike narratives of anti-Christianization, these hatred narratives toward those "deviant groups" in many cases transformed into physical violence by some radical groups who justify their terrors under the name "purification or fortification of faiths." Ironically, these terrors also targeted universities where intellectual freedom should be nurtured.

Radicalism in Yogyakarta is closely related to the narrative of an Islamic political order as an alternative to democracy. It idealizes an Islamic state or khilafah as a solution from world problems. Some informants believe that kbilafah is necessary and it is only a matter of time for its establishment. Muslims, they believe, are religiously obliged to prepare conditions or incentives for its coming. ${ }^{2}$ The narrative of kbilafah goes in line with the necessity for Muslims to implement Islam in a comprehensive way (Islam Kaffah) the integral parts of which are applying shari'ah and the establishment of an Islamic state or Khilafah Islamiyah. This is only by doing so that Muslims will recover from their current problems.

The above narrative is common among those who are affiliated with Islamist groups such as Hirbut Tabrir Indonesia (HTI) which strives to the

${ }^{2}$ Interview, September 30, 2013. 
establishment of an Islamic state or Khilafah. ${ }^{3}$ It is interesting to look at the answers from the informants who are not affiliated with similar groups. As this research found out, even though they show positive attitudes toward an Islamic political order, they nevertheless do not automatically reject democracy or Pancasila as the formal ideology of Indonesia. Unlike the first group, these informants, most of them are young Muslim activists, said that shariah is applicable only in forms of national legislation (formalization of shariab) rather than an Islamic political order or Islamic state. ${ }^{4}$

Extremism is characterized by the use of violence to realize Islamists visions. Radicalism transforms into extremism when it involves violence as the only way to change the situation considered against their idealized values or principals. Cultural values and strong civil societies in Yogyakarta do not give wide space for extremism in Yogyakarta. Being aware of the fact that Islamist violence strategy to change the current political order will attack the cultural foundations of the city, which are tolerant and antiviolence, Muslim radical groups alternatively switch to issues which are less theological and most people will likely buy such as pornography, lesbianism and so the likes. Under the term amr ma'ruf naby munkar (enjoining what is right and forbidding what is wrong), Islamist radical groups are trying to create a common word to justify their violent acts.

A number of violent acts and intimidation by Muslim radical groups were recorded in Yogyakarta. On March 20, 2011, Indonesia Islam Forum (FUI) sealed the quarter of Ahmadiyah in Kotabaru. On May 09, 2012 Majelis Mujahidin Indonesia (MMI) attacked a book discussion by Irshad Manji in Center for Studying Islam and Societies (LKiS). In addition to physical attacks, there were also intimidation and terrors by Islamic radical groups, particularly to Muslim sects who are considered deviant from "the true Islamic doctrine." Ironically, such intimidation and terrors targeted

\footnotetext{
${ }^{3}$ Noorhaidi Hasan, The Making of Public Islam Piety, Democracy and Youth in Indonesian Politics (Yogyakarta: SukaPress, 2013), 48.

${ }^{4}$ Interview, October 05, 2013.
} 
also universities and study centers where intellectual freedom should be given spaces. The most current case is on terror toward the movie screening titled Senyap at State Islamic University (UIN) Sunan Kalijaga.

In 2010, Yogyakarta people were shocked by the bombing at the front of Syubada Mosque. In 2013, Densus 88 arrested two suspected young terrorists, Muhammad Syaiful Sabani and Bayu Dwi Aryanto, in a hotel around downtown. Unlike extremism which found its grounds through the grand narratives of amr ma'ruf naby munkar in Yogyakarta, terrorism gains no acceptance at all among all the informants. For them, terrorism is not part of Islam and it derives from a misinterpretation of jibad. Nevertheless, our research shows that this grand narrative is expressed in different responses which in some cases are ambiguous as they entail rejections and sympathy at the same time, blaming terrorism upon 'external enemies' such as western policies and Zionist conspiracy. ${ }^{5}$

The question is then how the narratives of Islamism, with all its variants, spreads and gains its acceptance? To answer this question brings us to the relations between Islamism and its agency. Though the agency is personal, it is nevertheless shaped by the corresponding social settings. ${ }^{6}$ This research examined how Islamism disseminates in different social settings in Yogyakarta where universities, schools, and mosques are among the main loci.

In many universities, preaching institutions in campus or the so-called Lembaga Dakwah Kampus (LDK) plays a very significant role. These young Muslim organizations are found in either "secular" or Islam based universities. Their activities, which aim to establish "pious and true Muslim communities" particularly among young Muslim students, are built upon the belief that practicing Islam Kaffah (the holistic Islam) is the only solution for moral and political problems. Shariatization or Islamization for them refers to behaviors according to the Quran and

\footnotetext{
${ }^{5}$ Interview, July 09, 2013.

${ }^{6}$ Read Pierre Bourdieu, Outline of a Theory of Practice (London: Cambridge University Press, 1977).
} 
Hadith which quite often they understand them in a literal manner. They see Islam as an ideology which should reflect in any aspects of Muslims, including politics. Therefore, it is no wonder that they see ideology other than Islam as un-Islamic and, therefore, should be rejected. These young Muslim militants are very active in recruiting members through their regular activities and are mostly though not officially affiliated with larger political movements such as Hizbut Tabrir Indonesia or Partai Keadilan Sejabtera (PKS).

Islamism also infiltrates through the $L D K$ as well as it goes under the Islamic education sections or Kerohanian Islam (Rohis) in schools. In line with similar research by the Center for Religious and Cross-Cultural Studies (CRCS), Universitas Gadjah Mada, ${ }^{7}$ systematic efforts of "Islamization" in schools are reflected in their extracurricular activities. They also use bulletin boards as well as social media such as Facebook, Twitter, Youtube, or Blogspot. Like LDK, members of Rohis are connected to each other in a network called Inter-Rohis (Farohis) consisted of members and alumni of Rohis in each school. Mosques are also pivotal places for growing Islamism in Yogyakarta. It intertwines with an ideological polarization of mosques by Islamist groups in Yogyakarta. ${ }^{8}$ According to Qadir's ideology based categorization, the mosques in Yogyakarta are divided into moderate, political, formalist-sharia, and variant-puritanical. Each of which reflects on the colors of Islam.

\section{BNPT: Foe or Friend?}

Established in 2010, BNPT was mandated by the Indonesian government to deal with terrorism in Indonesia. BNPT declared war against terrorism which becomes a real threat particularly after $9 / 11$ and a series of bombings in the country. It is hard to deny the achievements of BNPT, along with Densus 88 , which successfully covered up the terrorist networks and caught their members. There are two main responsibilities

\footnotetext{
${ }^{7}$ Read Hairus Salim, et. al, Politik Ruang Publik Sekolah (Yogyakarta: CRCS UGM, 2011).

${ }^{8}$ Read Zuly Qodir, "Islam Kampus dalam Perubahan Politik Nasional: Studi Keislaman Masjid Kampus di Yogyakarta", Jurnal Muqaddimah, Vol, 18, No. 2, 2012.
} 
of BNPT in pacifying terrorism: enforcement and prevention. While the first takes the forms of "carrot and stick" approach in dealing with terrorists, the second involves into what so-called the national-wide "deradicalization" program.

Despite its success story, BNPT creates another problem which seemingly is counter-productive with its initial goals. Even though it is strongly and continuously rejected by the agency, in fact some Indonesian Muslims or Islamist groups accused it of targeting Islam. This is based on some controversial actions and policies by BNPT which are deemed as making Islam as the enemy. BNPT, through Densus 88 , was criticized for treating the terrorists and those suspected terrorists inhumanly: most of whom were deadly shot. Live reports by national media and videos on social media such as Youtube containing deadly attacks of Densus 88 against the suspects also fueled public rage and stirred demands for its disbandment. Harsh criticisms also came from human rights organizations, social activists, and also religious leaders.

The de-radicalization program creates resistance toward BNPT from some Islamist groups. For those groups, the de-radicalization program is an organized attempt to discredit Islam and, therefore, should be rejected. There were some cases where BNPT was criticized and even stirred demands for its dissolutions. In 2012, BNPT initiated a certification program for Islamic teachers which then almost all Islamic organizations and leaders strongly rejected: they also released a controversial statement that there are around 30 radical pesantren (Islamic boarding schools) in Indonesia. The most current and controversial issue, following the threats and recruitments of ISIS members in Indonesia, was the closing of around ninety Islamic websites due to their allegedly radical contents. This creates

\footnotetext{
${ }^{9}$ According to Ansyaad Mbay, as quoted by Zuhdi, the de-radicalization program aims to give a proper understanding of Islam, particularly on the meaning of Jihad. Read M. Harfin Zuhdi, "Fundamentalisme dan Upaya Deradikalisasi," RELIGIA Vol. 13, No. 1, April 2010, 92.
} 
controversy and harsh criticism and, again, insistence on the dissolutions of the agencies speaks louder.

The resistance toward BNPT is closely related to the agency's ideological approach in dealing with terrorism. Ansyaad Mbay, the head of BNPT, said that "Terrorism was rooted in radical ideology which takes the name of Islam." Even though the ideological approach turned to be effective in reducing and limiting spaces of terrorist attacks in Indonesia, it failed to prevent the evolution and transformation of terrorist networks into new cells. Reducing numbers of terrorist attacks may not indicate that they have been successfully swiped out or destroyed. Rather, they transform into new cells and new strategies. Therefore, a more cohesive and long-term counter-terrorism is necessary.

\section{Social Resilience: from Ideological to Cultural Approach}

The decreasing numbers of religiously motivated terrors in Indonesia at one point are good news and an indication of successful counterterrorism by the state. Sidney Jones, for example, stated that the counterterrorism program in Indonesia is one of the bests in the world. However, as indicated in the previous section, Islamism has potentials in it through which terrorists are recruiting their new members through ideological indoctrination. In a long term, cultural approach based counter-terrorism can best serve a protection from their radical and extremist ideology.

Yogyakarta may serve the best example. Being well-known as the heart of Javanese culture, the existing cultural values and wisdom become social capitals which can create social resilience against radical and extremist ideologies. Franz Magnis Suzeno mentioned that tolerance and respect for each other are ethical values, upon which Javanese world-views and ethics are built. These two principles of life become philosophical life of Javanese people as reflected in their motto "tata tentrem tata tur raharja" which literally means a harmonious and well-ordered life. ${ }^{10}$ This is why

\footnotetext{
${ }^{10}$ Frans Magnis Suseno, Etika Jawa: Sebuah Analisa Falsafi rentang Kebijksanaan Hidup Jawa (Jakarta: Gramedia, 2001), 38.
} 
Yogyakarta national-wide branded with its friendly attitude toward cultural and religious differences (the city of tolerance).

The tolerant faces of Yogyakarta can be historically traced back to three phases. Firstly, from its initial establishment as a Mataram Sultanate in 1756, Yogyakarta had been in open and harmonious encounters with different world cultures and religions. Secondly, in 1945-1949 when it was declared as the capital of the Indonesian Republic, Yogyakarta became a melting point of different ideas among the national and religious figures. In 1949, Yogyakarta declared its status as a multicultural society as young people of different regions and ethnicities were coming to the town to study at the oldest university in Indonesia, Gadjah Mada University, which was established in $1949 .{ }^{11}$ These three historical phases largely contributed to the tolerant characters of Yogyakarta.

Although Yogyakarta is currently facing the rising tide of Islamism, its existing cultures and local norms provide social capitals by which societies can prevent themselves from violent forms of Islamism. A social and cultural mechanism such as Javanese rituals (e.g. nyadran, ruwatan, and kenduri) can strengthen social cohesion and solidarity which limits spaces for the growth of ideology based alienated groups. A strongly charismatic personality in Sri Sultan Hamengkubuwono XI constitutes also as "a local hero" who stands at the front line of multiculturalism along with other moderate Muslim leaders. As a center of education, Yogyakarta also provides a strong basis for the education of multiculturalism in schools where children are taught how Islam is supportive of multiculturalism and against terrorism. Yogyakarta is also rich with numbers of civil societies who promote tolerance and anti-violent movements. Working together, these social capitals would be able to build contra-narratives against the spread of violent imported ideologies such as Islamism.

${ }^{11}$ Herry Zudianto, Kekuasaan sebagai Wakaf Politik: Manajemen Yogyakarta Kota Multikultur (Yogyakarta: Kanisius, 2008), 51-65. 


\section{Conclusion}

Well-known as a city of tolerance, Yogyakarta is currently facing the rising tide of Islamization, especially in mosques, schools, and universities. This new development brings the region into more polarized societies of different religious and ethnic groups. This religious symbolism oriented development also put religion as a marker of identity where tolerance toward others is demarcated by theological terms, creating what the socalled a lazy tolerance. Fueled with religiously motivated hate speeches, this kind of lazy tolerance is potentially leading to violent forms of Islamism.

Infiltration of radical Islamist groups into public space can transform religious militancy into radicalism or even violent forms of Islamism (extremism and terrorism), particularly when joining with illusive dreams offered by those groups. The appeals of religious radicalism usually lie in the belief that Muslims today are undergoing setbacks and helplessness due to their ignorance of shariah, lack of solidarity or unity among Muslims, and conspiracy of what the so-called "enemies of Islam." This is not to mention also poverty, corruption and other social problems which become an integral part of the radical groups' campaign in recruiting their members.

Resistance towards de-radicalization and counter-terrorism program by the state also indicates that ideological approaches, even though very successfully in its enforcement efforts, should go hand in hand with cultural ones if the program wants to give more long-lasting impacts. Even worse, this gap in fact provides fuels for radical and terrorist groups to continuously spread their narratives of anti-government and "back to shariab" or violent jihad as the only solution.

Yogyakarta, which is the heart of Javanese culture, has rich social capitals to anticipate violent forms of Islamism. Javanese philosophy of life, traditions and local wisdom in the region could be an effective medium to fight radicalism and terrorism. In addition, the number of peace-making groups, interfaith organizations and other similar civil societies can largely contribute to the program of the state. 


\section{Reference}

Bourdieu, Pierre. Outline of a Theory of Practice. London: Cambridge University Press, 1977.

Hasani, Ismail, ed. Radikalisme Agama di Jabodetabek \& Jawa Barat. Jakarta: Setara Institut, 20011.

Hasan, Noorhaidi, et al. Instrumen Penelitian: Narasi Islamisme dan Politik Identitas. Yogyakarta: Fakultas Syariah \& BNPT, 2013. .The Making of Public Islam Piety, Democracy and Youth in Indonesian Politics. Yogyakarta: SukaPress, 2013.

Halverson, Jeffry R., Steven R. Corman, and H. L. Goodall Jr. Master Narratives of Islamist Extremism. New York: Palgrave MacMillan, 2011.

Salim, Hairus (eds.), Politik Ruang publik Sekolah, Yogyakarta, CRCS UGM, 2011.

Shidqi, Ahmad, Sepotong Kebenaran Milik Alifa, Yogyakarta: Kanisius, 2008.

Suseno, Frans Magnis, Etika Jawa: Sebuah Analisa Falsafi tentang Kebijksanaan Hidup Jawa, Jakarta: Gramedia, 2001.

Turmudi, Endang, and Riza Sihbudi. Islam dan Radikalisme di Indonesia. Jakarta: LIPI Press, 2005.

Zudianto, Herry. Kekuasaan sebagai Wakaf Politik: Manajemen Yogyakarta Kota Multikultur. Yogyakarta, Kanisius, 2008.

Zuly Qodir. "Islam Kampus dalam Perubahan Politik Nasional: Studi Keislaman Masjid Kampus di Yogyakarta." In Jurnal Muqaddimah, Vol, 18, No.2, 2012.

Zuhdi, M. Harfin. "Fundamentalisme dan Upaya Deradikalisasi." in RELIGIA Vol. 13, No. 1, April, 2010.

\section{Online sources:}

Merdeka.com, 13/10/2009

Sindonews.com, 13/08/2013.

Http: voa-islam.com, 20 Sept 2012

Http:// republika. co.id, 5 Juni 2012.

Http:/ / farohis-jogja.blogspot.com/,

Http://muslim.or.id.

Https://www.facebook.com/groups/388410194521870/

http://nasional.tempo.co/read/news/2011/10/05/173360080/indonesi

a-dinilai-rawan-radikalisme-dan-terorisme

http://www.thejakartapost.com/news/2008/11/26/most-islamic-

studies-teachers-oppose-pluralism-survey-finds.html 